\title{
INNOVATIVE RESOURCES FOR PROMOTING ACADEMIC WRITING SKILLS IN ENGLISH CLASSES
}

\author{
Ivashchyshyn O. M. \\ Candidate of Philological Sciences, Associate Professor, \\ Associate Professor at the Department of Foreign Languages for the Humanities \\ Ivan Franko National University of Lviv \\ Universytetska str., 1, Lviv, Ukraine \\ orcid.org/0000-0002-5666-7766 \\ ivasho@gmail.com \\ Kashchyshyn N. Ye. \\ Candidate of Philological Sciences, Associate Professor, \\ Associate Professor at the Department of Foreign Languages \\ Ivan Franko National University of Lviv \\ Universytetska str., 1, Lviv, Ukraine \\ orcid.org/0000-0003-0005-4685 \\ natakashchyshyn@gmail.com
}

\section{Key words:}

Academic Writing, innovative resource, learning environment, Information technology, online learning, interactive assignment.
The article considers the results of implementing a new methodology of teaching Academic Writing (AW) as a constituent part of integrated English classes to Philology and International Relations students in Ivan Franko National University of Lviv. It emphasizes the role of English AW due to the integration of Ukraine in European educational space, incorporation of Information technologies into teaching environment and the intensive development of online education caused by a pandemic spreading of Covid-19 throughout the world. The article studies the main characteristic features and rules of AW on the basis of theoretical investigations of famous methodologists and linguists. The discussion on such basic strategies as striving for clarity and communicating ideas effectively is at the heart of the article. Besides that, the article emphasizes the importance of structure and design, grammar and logical organization of paragraphs as well as the necessity of revising the text and the use of transitions between sentences and paragraphs to help readers follow the ideas easily.

The article investigates the existing approaches to conducting online classes and focuses on the use of "Teaching and Learning Academic Subjects" (TALAS) management system that creates an online environment for teaching English, including AW. The main focus is on the discussion of TALAS tools for writing assignments, which provide the opportunity to learn AW on the basis of theoretical material and practice knowledge through interactive tests. The students can also write essays, summaries, reviews, CVs, conference abstracts, etc. The evaluation system of TALAS provides students with the opportunity to see the mistakes and read the remarks and advice of the teacher. This challenges the promotion of writing skills, makes the process of learning AW manageable and successful and brings innovative perspectives to teaching writing.

Finally, the article emphasizes that based on students' feedbacks on learning AW, TALAS helps in promoting writing skills, makes learning more effective and more transferable to new situations in contemporary education. This encourages to conclude that the applied methodology is a resource effectively contributing to students' AW knowledge acquisition. 


\title{
ІННОВАЦЙНІ РЕСУРСИ ДЛЯ РОЗВИТКУ НАВИЧОК АКАДЕМІЧНОГО ПИСЬМОВОГО МОВЛЕННЯ НА ЗАНЯТТЯХ З АНГЛІЙСЬКОЇ МОВИ
}

\author{
Іващишин О. М. \\ кандидат філологічних наук, дочент, \\ дочент кафедри іноземних мов для гуманітарних факультетів \\ Львівський національний університет імені Івана Франка \\ вул. Університетська, 1, Львів, Україна \\ orcid.org/0000-0002-5666-7766 \\ ivasho@gmail.com \\ Кащишин Н. $\mathbf{C}$. \\ кандидат філологічних наук, доиент, \\ доцент кафедри іноземних мов \\ Львівський національний університет імені Івана Франка \\ вул. Університетська, 1, Львів, Україна \\ orcid.org/0000-0003-0005-4685 \\ natakashchyshyn@gmail.com
}

\begin{abstract}
Ключові слова:
академічне письмове мовлення, інноваційний ресурс, навчальне середовище, інформачійні технологї, онлайн-навчання, інтерактивне завдання.
\end{abstract}

У статті розглянуто результати впровадження нової методики викладання академічного письмового мовлення (AW) як складової частини інтегрованих занять 3 англійської мови для студентів філологічного факультету та факультету міжнародних відносин у Львівському національному університеті імені Івана Франка. Вона наголошує на ролі англійського письмового мовлення 3 огляду на інтеграцію України в європейський навчальний простір, впровадження Інформаційних технологій у навчальне середовище та інтенсивний розвиток онлайн-освіти, спричинений пандемічним поширенням Covid-19 у всьому світі.

У статті вивчаються основні характерні ознаки та правила AW на основі теоретичних досліджень відомих методистів та лінгвістів. У центрі уваги $€$ обговорення таких основних стратегій, як прагнення до ясності та ефективне висловлення ідей. Окрім того, у статті наголошується на вагомості структури та дизайну, граматичної та логічної організації абзаців, а також на необхідності перевірки тексту та використанні перехідних зв'язків між реченнями і абзацами для того, щоб допомогти читачам легко сприймати ідеї.

У статті досліджуються існуючі підходи до проведення онлайн-занять та зосереджується увага на використанні системи управління TALAS, яка створює Інтернет-середовище для викладання англійської мови, включаючи AW. Основну увагу зосереджено на обговоренні ресурсів TALAS для письмових завдань, які забезпечують можливість вивчення AW на основі теоретичного матеріалу та практичного засвоєння знань за допомогою інтерактивних тестів. Студенти також можуть писати есе, анотації, рецензії, резюме, тези доповідей конференцій тощо. Система оцінювання TALAS надає студентам можливість побачити помилки та прочитати зауваження і поради викладача. Це сприяє розвитку навичок письма, робить процес керованим i успішним та створює інноваційні перспективи для викладання AW.

У завершальній частині статті наголошується, що грунтуючись на відгуках студентів щодо вивчення AW, TALAS допомагає у розвитку письмових навичок, робить навчання більш ефективним, 3 можливістю застосовуватись у нових ситуаціях сучасної освіти. Це спонукає до висновку, що використана методологія $\epsilon$ ресурсом, який робить ефективний внесок у засвоєння знань з AW студентами. 
Problem statement. Academic Writing (AW) has continuously been in the focus of educators, linguists and language methodologies trying to search innovative ideas in order to make teaching writing most effective for learners. With the development of new approaches to language teaching and integration of innovative technologies in education, the elaboration and implementation of new resources for promoting writing skills have become the crucial components in English teaching context.

Our article considers the results of research in the field of implementing a new methodology of teaching English to Philology and International Relations students in Ivan Franko National University of Lviv. On the one hand, it reflects the experience of developing new curriculum for teaching English in contemporary academic environment with the pandemic spreading throughout the world caused by COVID-19 when an online learning plays an important role and is of a great help in the educational process. In this situation even the most conservative universities have started the transformation towards innovations in order to develop online education system and make it accessible to all students. On the other hand, the article discusses the promotion of English AW skills based on the use of specific online resources developing English competence in contemporary educational medium.

The topic of the article is significant due to the requirements caused by a new world life situation as well as the orientation of Ukrainian education to integration in the European community where English communication is of great importance. The necessity to use new tools in language education was also caused by the requirements of contemporary world to implement Information technologies in teaching processes and develop students' writing skills for their future professional communication via the Internet. Nowadays, English classes integrate developing oral communication skills and promoting AW skills which are getting more and more important. Applying online resources for these purposes is of great significance in contemporary education.

Our research is based on the approaches supported by such authors as D. Hacker [1], I. Lecki [2], R. Spack [3], K. Vesela [4], T. Yakhontova [5] who focus on various methods of teaching AW. Moreover, literature in the area of computer-assisted language learning has pointed to the importance of incorporating a variety of tools for teaching purposes [6, p. 104; 7, p. 148] and the advantage of interactive electronic media in intensifying the learners' perceptions, cognitions and experiences $[8$, p. $153 ; 9$, p. 26]. From the point of view of J. Harris, an emphasis on the use of the innovative methodology leads one to notice that technologies applied to teaching constitute an excellent means of learning and teaching [10, p. 53]. According to M. Gonzalez-Lloret, suitably designed computer-assisted tasks enable greater individualization and make it possible to cater more fully to learners' individual needs and learning styles [11, p. 92].

The article considers the results of both theoretical investigations and their practical implementation, as well as suggests a new methodology based on the integration of innovative resources in teaching AW for achieving the goals of developing students' skills through interactive online tests and writing assignments.

According to T. Yakhontova, writing is a complex process that requires a number of various skills [5, p. 18]. AW is one of the highest forms of English writing. It has always had a central role in teaching English at academic institutions. Even in integrated English classes, AW is a constituent part of the curriculum. Moreover, AW serves as a tool of communication that conveys acquired knowledge in a specific field of study. Students are taught to write academically, think critically and objectively, look at ideas and research from different perspectives, analyze theories from different viewpoints and then write based on what they understand and know.

$\mathrm{AW}$ is different from such forms of writing as Legal writing, Business writing, Creative writing, etc. J. Fulbright has expressed the idea that AW is more structured and formal than Creative writing, following stricter guidelines and rules, and is more important than Creative writing for scholastic success, is rigid and procedural, is purposed purely to convey knowledge, information and is orderly, organized, and follows a formula [12, p. 1]. Even the font and font size are important for AW papers. They are characterized by a clear introduction, body and conclusion as well as specific content and language features.

According to D. Hacker and I. Lecki, AW has a strong point for the reader, evidence to support the point being made and impersonal style of expressing ideas [1, p. 92; 2, p. 105]. We share the opinion of R. Spack that learning how to write academically allows students to explain what they know by following the correct structure, using the appropriate language and grammar, striving for clarity, consolidating and communicating ideas effectively [3, p. 58]. $\mathrm{K}$. Vesela emphasizes the necessity of logical organization for the details in paragraphs and revising the sentences and paragraphs so that they are linked to one another in ways that help readers follow them easily [4, p. 32]. Learning above mentioned features of AW papers brings students a huge step getting closer to mastering writing skills.

It can be difficult for students to explain in their writing what they know, especially on complex subjects, if they are poor in AW. In terms of that, it is important to promote students' writing skills. Applying innovative methodology for the purpose in teaching AW in English classes on both theoretical and practical basis is of great help nowadays. 
In fact, contemporary education requires modernization of methods for teaching various academic subjects including languages. The days when a printed textbook was the learners' only aid are quickly vanishing, and teachers are faced with questions of how to integrate different innovative resources into their classes. Many teachers, even those who have had the reputation for adhering to more traditional approaches are increasingly looking for ways to incorporate online resources into their teaching. In this article, some of these ways are discussed.

Purpose of the article. Our article contributes to the development of new methodology of teaching AW. The main focus is on promoting writing skills in virtual environment addressing new challenges in the age of innovative technologies. Our belief is that the type of learning environment is a determining factor in effective development of students' writing skills. In contemporary education, it is of great significance to try out various of tools and incorporate Information technologies into teaching writing.

The purpose of our research is to analyze existing resources for teaching AW in English classes and suggest the use of "Teaching and Learning Academic Subjects" (TALAS) web-application [13] which has been implemented in teaching English, including AW. This web-application allows to integrate both theoretical and practical approaches to learning AW. Our task is to show the advantage of applying computer environment with well-organized interactive tasks in intensifying the learning processes.

The discussion on the main tools, strategies and assignments of TALAS, which help in learning the rules of AW involving a great deal of planning, striving for clarity, consolidating and communicating ideas effectively in AW papers is at the heart of the article. Besides that, the article emphasizes the importance of document design, grammar, punctuation, logical organization of paragraphs as well as the necessity of revising the text and the use of transitions between sentences and paragraphs to help readers follow the ideas easily. Finally, the article shows in what way TALAS provides the opportunity to learn the rules of AW and practice them in online tests and writing assignments.

Presentation of the main material. Nowadays, the Internet resources have penetrated in all areas of education. Online learning is becoming an effective multimedia environment using educational technology. It is also described by such terms as: webbased learning, learning via the internet, Distance Education, computerized electronic learning, etc. It is the type of learning environment specifically delivered via the internet to students and conducted by the teacher in a virtual classroom. The students can interactively communicate with the teachers and other students in this virtual classroom. Such modern online educational platforms as Microsoft Teams, Zoom, Google Meet, Cisco Webex, etc. allow even to raise hand "electronically" or interact in real time. A teacher can grade the students' participation, give the assignments and tests. In fact, online learning has been proven to be a successful method of training and education is becoming a way of life for many students. It is a very convenient and flexible option. Among the advantages of online learning are the following: the students are able to link the various resources in several varying formats; it is a very efficient way of delivering courses online; due to its convenience and flexibility, the resources are available from anywhere and at any time; everyone can take advantage of active and independent web-based learning through online learning management system.

The most world's trusted and popular learning management system is Moodle which is the platform used by hundreds of millions of users worldwide to support their education and training needs $[14, \mathrm{p} .1]$. It is developed on pedagogical principles and is used to achieve learning goals in various fields. Moodle is also widely used to create online language courses including those which contribute to developing students' writing skills.

Besides the resources mentioned above, in teaching AW we use an online management system TALAS. It is a web-oriented application that helps the students acquire language competence, including developing and practicing AW skills, provides them with tools for acquiring theoretical knowledge and fulfilling interactive writing assignments. TALAS is a multifunctional environment. It challenges the promotion of writing skills, makes this process manageable, and brings innovative perspectives to teaching writing. TALAS is based on the work of two types of users: a teacher and a student. It provides the teacher with the tools for creating theoretical material, applying video and audio resources as well as elaborating interactive practical assignments for developing students' writing skills. TALAS allows the students to write essays, summaries, reviews, CVs, conference abstracts, etc. This web-application is for both students' group and individual activities and supports monitoring student's progress results with the help of the evaluation system. Besides that, TALAS enables the students to view their mistakes and read the teacher's explanations. It creates a new learning space in which the users are autonomous. In addition to interactive assignments and AW opportunities, this web-oriented application supports embedding YouTube videos and audio resources for conducting AW writing classes.

While leaning AW based on TALAS web-application, the students use the tool "AW course" to 
start fulfilling the task of the teacher. They learn the theoretical material relating to the topic of the lesson and practice it through online tests developed by the teacher. In the theoretical part of the course, the rules of AW are the constituent elements. Among the many important topics, the Peer Review Checklist plays one of the most significant role. It helps understand the standard requirements to writing a specific paper including the outline of the format, the correspondence to the title, logical and effective development of ideas making a reader want to keep reading, satisfying organization of the paper and paragraphs with supporting examples and transitions to the next paragraph, relevant language, grammar and style as well as visual presentation.

The final stage for the students is to fulfill the writing assignment. TALAS tool for this online activity is located in practical part of web-application and includes the title, task, field for writing and a submission button. After fulfilling the task and submitting the required paper, the students can see the results of teacher's examination and corrections in "Teachers notes" below the paper, as well as evaluation of students' writing in "Overall results". This provides the students with the opportunity to see the mistakes and take into account the advice of the teacher. The evaluation system of students' work challenges the promotion of writing skills, makes this process manageable and successful and brings innovative perspectives to teaching writing. Well-organized and easy in operation TALAS web-application equipped with the tools for promoting writing skills offers a new way of acquiring knowledge and calls for a re-interpretation of the English teaching paradigms.

Conclusions. To summarize, teaching English AW has undergone innovative changes caused by the requirements of the integration of Ukrainian education into European educational space where communication in English plays an important role. The innovative changes have also been caused by pandemic spreading of COVID-19 throughout the world and the consequent transformation of education towards creating online learning environment delivered via the Internet and proven to be a successful, convenient and flexible option. Students can link the various resources and take advantage of webbased independent learning as well as interact with the teacher online. All that gave a strong impulse to developing new curriculum and designing new language courses integrating AW and Information technologies. Among the many Internet resources, TALAS as a web-oriented application described in this article, can be effectively used for teaching various aspects of English including AW. TALAS provides the tools for learning theoretical material on the rules and features of AW and practicing it in interactive assignments.

According to our observations, the implementation of TALAS has resulted in an increase in learning motivation as well as the creation of effective learning space. Besides that, the results of teaching AW to students in TALAS environment have confirmed successful outcomes of developing students' writing skills in the course of fulfilling online tests and interactive writing assignments. The students' feedbacks have confirmed that TALAS facilitates self-learning process, promotes knowledge acquisition, makes learning faster, more enjoyable, more self-directed, more effective and more transferable to new situations in contemporary education. This encourages to conclude that the applied methodology is a resource effectively contributing to students' writing knowledge acquisition.

The experience described in this article can be useful for designing new courses integrating AW and Information technologies. We hope that these strategies can be replicated or adapted by other teachers to suit their particular teaching and learning contexts. Finally, we believe that the theoretical considerations and practical principles that shape the contribution of our methodology will help in developing new approaches to teaching AW in English classes.

\section{References}

1. Hacker D. (2020) Rules for Writers. New York : St. Martin's Press. 656 p.

2. Lecki I. (1995) Academic Writing. New York : St. Martin's Press. 433 p.

3. Spack R. (1996) Guidelines: A Cross-cultural Reading/Writing Text. New York : St. Martin's Press. 504 p.

4. Vesela K. (2012) Teaching ESP in New Environments. Nitra : ASPA. 114 p.

5. Yakhontova T. (2002) English Academic Writing for Students and Researchers. Lviv : Publishing Center of Ivan Franko LNU. 218 p.

6. Dudeney G., Hockly N. (2007) How to Teach English with Technology. Harlow : Pearson Education Limited. $289 \mathrm{p}$.

7. Keedwell A. (2013) Blended learning for English for Occupational Purposes: No frills, soft skills, gaps filled. Blended Learning in English Language Teaching: Course Design and Implementation. London : British Council. P. 147-154.

8. Chun D., Plass J. (2000) Networked multimedia environments for second language acquisition' in Network-based language teaching: concepts and practice. New York : Cambridge University Press. P. 151-170. 
9. Felix U. (2002) The Web as a vehicle for constructivist approaches in language teaching. London : Longman. P. 22-31.

10. Harris J. (2001) Structuring internet-enriched learning spaces. Learning \& Leading with Technology. № 28(4). P. 50-55.

11. Gonzalez-Lloret M. (2003) Designing task-based CALL to promote interaction. Language Learning and Technology. № 7. P. 86-104.

12. Fulbright J. Academic Writing vs. Creative Writing. URL: http://www.jeanniefulbright.com/2008/07/academic-writing-vs-creative-writing (Cited: 8.10.2020).

13. Ivashchyshyn O., Dovbenko V. TALAS. URL: http://talas.dx.am/about.php (Cited: 4.11.2020).

14. Moodle LMS. URL: https://moodle.com/lms/ (Cited: 8.10.2020). 